\title{
BLOWING UP THE NUCLEAR FAMILY: SHIRLEY JACKSON'S QUEER GIRLS IN POSTWAR US CULTURE ${ }^{1}$
}

\author{
LAURA DE LA PARRA FERNÁNDEZ \\ UNIVERSIDAD NEBRIJA \\ lparraf@nebrija.es
}

Received 22 July 2020

Accepted 11 December 2020

KEYWORDS: Shirley Jackson; postwar US fiction; nuclear power; gender studies; girlhood studies.

PALABRAS CLAVE: Shirley Jackson; ficción estadounidense de la posguerra; energía nuclear; estudios de género; adolescencia femenina.

\begin{abstract}
This paper intends to analyze the representation of girlhood as a liminal space in three novels by Shirley Jackson: The Bird's Nest (1954), The Haunting of Hill House (1959) and We Have Always Lived in the Castle (1962). Bearing in mind how nuclear fears and national identity are configured around the ideal of a safe domestic space in US postwar culture, the paper explores cultural anxieties about teenage girls who refuse to conform to normative femininity, following Teresa de Lauretis's conception of women's coming-of-age as "consenting to femininity" (1984). I will argue that Jackson criticizes the rigid possibilities for women at this time, and I will show how her representations of deviant femininity refuse and subvert the discourse of the nuclear family and, therefore, of the nation.
\end{abstract}

\footnotetext{
1 This research was carried out thanks to a Visiting Fellowship for Doctoral Research Fellows granted by the Spanish Ministry of Education (reference: EST2016/0055) for a short research stay at Birkbeck College, University of London. The author wishes to acknowledge the support of the project "Improvisation and Emotional Contagion. History and Philosophy of Emotional Experiences," funded by the Spanish Ministry of Science and Innovation (reference: PID2019-108988GB-IO0).
} 


\section{RESUMEN}

El presente artículo pretende analizar la representación de la adolescencia femenina como un espacio liminal en tres novelas de Shirley Jackson: The Bird's Nest (1954), The Haunting of Hill House (1959) y We Have Always Lived in the Castle (1962). Teniendo en cuenta cómo los temores nucleares y la identidad nacional se configuran en torno al ideal de un espacio doméstico seguro en la cultura estadounidense de la posguerra, el artículo explora las preocupaciones culturales acerca de las adolescentes que se niegan a ajustarse a la feminidad normativa, siguiendo la concepción de Teresa de Lauretis de la madurez femenina como la "aceptación la feminidad" (1984). Se argumentará que Jackson critica las rígidas posibilidades que existian para las mujeres en ese momento, y se demostrará cómo sus representaciones de una feminidad desviada rechazan y subvierten el discurso de la familia nuclear y, por lo tanto, de la nación.

\section{INTRODUCTION}

Girls did not always exist. Or, at least, they were not and should not be seen. As Catherine Driscoll contends, the discourse of modern girlhood does not arise until late-nineteenth-century debates about suffrage and industrial society (14). However, at the turn of the twentieth century female adolescence became charged with discourses of crisis and moral panic about cultural anxieties, particularly issues such as sexuality or mass consumption (Driscoll 14). ${ }^{2}$ Similarly, during the postwar period, "the adolescent girl also became at this time a standard reference point" of the changing discourse of modernity and the emerging social order as well as an important consumer (Driscoll 18). ${ }^{3}$ However, the discourse of the modern girl is traversed by clashing ideals of new, post-industrial nations, as well as by different axes of modernity and tradition, and as such embodies "an index of the problem of the present" (Driscoll 15) in the twentieth-century Western world. Bearing in mind the rapid change in women's roles in society in such a short span of time-from the late Victorian period until after WWII-the teenage

\footnotetext{
2 See for instance Andreas Huyssen's "Mass Culture as Woman" (1987), where he relates mass culture with the "new woman" of the early twentieth-century who began to appear in public urban spaces, in particular department stores and high streets.

${ }^{3}$ See Scrum (2004) and Nash (2006) on the rise of teenage girls' culture.
} 
girl appears as a site of reification, contestation and transformation of cultural practices, sometimes all at once.

As Elizabeth Lunbeck argues, adolescent girlhood posed a threat just by existing since its inception, with the rise of the rights to education and literacy granted to girls, new pink-collar jobs and mass urbanization (188-189). If for a man these "were years of experimenting and searching for an identity, in the case of girls were years in which she was to submerge, rather than free, her yearnings for independence, years in which she was to reconcile herself to her dependence on men and the inevitability of marriage. They were years best avoided altogether" (Lunbeck 189). Thus, if for a man adolescence means a transition period between childhood and adulthood, where he is to gain the skills and independence that will allow him to make a living for himself and his family, in a woman adolescence would mean accepting that she will never become fully independent-and will go instead from being a daughter to being a mother and a wife. The girl becomes at once a marker of modernity and its dangers, which, according to the socio-scientific imagination included sexual depravity and an excess of worldliness (DeLuzio 139-140), putting at risk the ideal of the family.

Shirley Jackson's characters are often single young women, like eighteen-year-old Merricat in We Have Always Lived in the Castle (1962); or not quite grown women: twenty-three-year-old Elizabeth in The Bird's Nest (1954) and thirty-two-year-old Eleanor Vance in The Haunting of Hill House (1959). These characters could be considered girls within the definition of girlhood as a liminal period: they have not yet achieved female maturity, that is, the protagonists of these novels have not followed through with the heterosexual love plot and have not yet become mothers. As such, they are presented as "social misfits" (Carpenter "Domestic Comedy" 145), whom society will try to force to perform normative femininity. These characters metaphorically "blow up" the nuclear family by disentangling its complex power dynamics and unveiling abuse from parents and supposedly care figures-including medical authorities-putting at danger the unity of the community. The girls' refusal to "consent to femininity," following Teresa de Lauretis (133), sets in motion a series of mechanism of control, punishment and ultimate alienation from society. In other words, girls are asked to subject themselves to the performance of normative femininity, following Judith Butler's idea of gender as a regulatory practice of identity (1990), that is, undergoing 
the heterosexual love plot, reproducing the family and thus, the nation, in order to belong to society.

Further, Jackson's "queer girls" are pathologized and put under medical treatment in order to be "cured," as in the case of Elizabeth and Eleanor. This goes hand in hand with medical theories of the period, which were strongly influenced by psychoanalysis (Scull 2014) as well as by essentializing biologist theories wary of female independence. Thus, it was believed that deviation from a normative performance of gender might lead to sexual autonomyeven in adult women (DeLuzio 138). ${ }^{4}$ The fear that the female adolescent could disrupt the social fabric through a dismemberment of the nuclear family is portrayed as the main motive for the girls' enduring infantilization. Jackson's novels hence evince the familial abuse that leads the characters to search for an identity and a community of care outside the nuclear family, and the punishment they receive for doing so: removing their identity (Elizabeth); being propelled to suicide (Eleanor); or complete isolation, like radioactive waste that may otherwise pollute the community (Merricat).

In a similar vein, the fact that Jackson's fiction was never considered to be "serious" literature because it was often published in women's journals in the 1950s, and that she presented herself as a "housewife writer" (Carpenter, "Domestic Comedy" 143), reinforce the potential of speaking from the margins, if only to rupture them. In fact, Jackson's Gothic undertones have sparked great intrigue. Authors have linked her use of the Gothic mode to the representation of trauma (Nadal 2011), as well as to the exploration of the unconscious (Hattenhauer 2003) or the portrayal of lesbian identity (Lootens 2005). While Jackson's own problematic mother/daughter relationship has heavily impacted academic criticism and scholarship on Jackson's work, ${ }^{5}$ I wish to look at how Jackson bestows the most powerless members of US postwar society and its future heirs-daughters-with the power to undermine the core of its foundations.

\footnotetext{
${ }^{4}$ Authors such as De Luzio (2007) claim that G. Stanley Hall's foundational study, Adolescence (1904), with a Lamarckian background, has deeply influenced the way that contemporary society understands adolescence.

${ }^{5}$ See for instance Rubenstein (1996), Hattenhauer on Jackson's "phallic mothers" (1011) or the first published biography about Shirley Jackson, Oppenheimer's Private Demons: The Life of Shirley Jackson (1988).
} 
In this article I will explore how three of Jackson's novelsThe Bird's Nest (1954), The Haunting of Hill House (1959) and We Have Always Lived in the Castle (1962) - portray girlhood as a period that is pathologized when the novels' female protagonists refuse to "consent to femininity" and therefore pose a threat to the national ideal of the nuclear family. In order to carry out my analysis, I will first establish how the metaphor of the nuclear family as nuclear power can be used to understand discourses about national stability, global dominance and gender roles, as well as the dangers that lead to a community's self-destruction. I will then examine how deviant performances of femininity in Jackson's female protagonists are stigmatized, medicalized, and ultimately forced to conform to normative gender roles or otherwise rejected from society. However, I will also argue that the liminality of this age period-between adolescence and maturity-allows the protagonists to subvert the status quo and the discourse of the family and nation, even if little agency is afforded to them. Girls are not only future women-and as such gatekeepers of the symbolic and material reproduction of the nation-, they are not adults yet. This invests girls with a powerful transformative potential to challenge hegemonic discourses about gender, sexuality and the necessary conditions for belonging.

\section{NUCLEAR FEARS: SHELTERING THE NUCLEAR FAMILY}

One thing that defined domestic politics in postwar US was the identification between family and the nation, if only a specific type of family. According to Elaine Tyler May, "[a]lthough the nation remained divided along lines of race and class, and only members of the prosperous white middle and working classes had access to the suburban domesticity that represented 'the good life,' family fever swept the nation and affected all Americans" (3). This family is no other than the so-called "nuclear family." Indeed, the use of this term was popularized in 1941, when family units became smaller due to postwar socioeconomic and urban policies promoting life in the suburbs. ${ }^{6}$ The term "nuclear family" stems from atomic fission, as "nuclear energy" does: it is the energy provided by the elements of a core unit. In this sense, each of the members in a nuclear family also fulfills a fundamental action: the father is the breadwinner, the

${ }^{6}$ On the relation between suburbia and the "good life" in postwar US culture, see Jackson (1985). 
mother is the consumer and carer of the future individuals of society, children, who are invested, as Lee Edelman argues, with the paramount value of the nation's futurity (6).

Even if this "good life" was not attainable for everyone, this ideal was promoted both inside and outside the nation as if it were so. In the "Kitchen Debate" between the then US Vice President Richard Nixon and Soviet Prime Minister Nikita Khrushchev at the American National Exhibition in Moscow in 1959, they did not actually discuss political ideologies, nuclear weapons, or the economy. Rather,

Nixon insisted that American superiority in the cold war rested not on weapons, but on the secure, abundant family life of modern suburban homes. In these structures, adorned and worshipped by their inhabitants, women would achieve their glory and men would display their success. Consumerism was not an end in itself; it was the means for achieving individuality, leisure, and upward mobility. (May 21)

Thus, capitalism and national ideals were intrinsically tied to the domestic and private sphere, and "marriage itself symbolized a refuge against danger" (May 103). Further, marriage and the family act as a shelter to provide security in times of uncertainty. The family also protects individuals against the threat of Communism: if men worked enough, America would thrive; if women cared for these men and reproduced and reared the labor force, technological and economic progress was assured.

Although modernity propelled the economy to the point of situating the US at the top of worldwide economic and political powers, there were fears that this advantaged situation would also threaten the domestic realm. As May suggests, "[f]ears of sexual chaos tend to surface during times of crisis and rapid social change" (90). Hence family stability was endorsed to counteract other related dangers, such as the outbreak of a nuclear war. In fact, some scholars connect the dangers of atomic warfare to the destruction of the family. For instance, in 1951 Charles Walter Clarke, a Harvard physician, published an article in the Journal of Social Hygiene claiming that "[f]ollowing an atom bomb explosion [...] families would become separated and lost from each other in confusion. Supports of normal family and community life would be broken down. [...] There would develop among many people, especially youths $[\ldots]$ the 
reckless psychological state often seen following great disasters" (Clarke qtd. in May 90). Instead of focusing on the death and destruction that an atomic bomb could cause, Clarke focused on the moral and sexual chaos that would ensue the attack-venereal disease, prostitution, and immorality-which would then cause the disintegration of society. While Clarke had studied venereal disease for years and his idea "did not represent mainstream medical opinion" (May 90), most applauded his ideas when he sent a draft of the article to medical authorities. The nuclear family, living in idyllic, consumer-oriented suburbia, encapsulated the new possibilities of postwar American life, but it also contained the seed of its own destruction: if any of the members became dysfunctional, the nucleus would be split and, following the logic of atomic fission, a chain reaction would start, dismembering society.

In order to avoid this, domesticity became ideologically linked to the political and economic advancement of the US as a nation in the global context:

The modern family would, presumably, tame fears of atomic holocaust, and tame women as well. With their new jobs and recently acknowledged sexuality, emancipated women outside the home might unleash the very forces that would result in a collapse of the one institution that seemed to offer protection: the home. For women, the rewards offered by marriage, compared to the limited opportunities in the public world, made the homemaker role an appealing choice. (May 108)

This is why, during the postwar period, ideals of femininity related to domesticity, care, reproduction and "being-for-others" become a sort of "being-for the nation" (Ahmed 124), similar to the way in which the Victorian "Angel-in-the-House" supported the British empire through her embodiment of purity and the reproduction of national values in the home. Thus, compulsory heterosexuality (Rich 1989), marriage and reproduction are closely linked with the reproduction of the nation, both in a material and in a symbolic way, through unpaid housework, the breeding of future citizens and workers, and their upbringing within the socially established discourses (Fraser 28-30). However, this, in turn, confers great power upon women within the domestic realm-so much so that the abandonment of their duties could provoke the downfall of the institution that most effectively protects and manages citizens: 
the family. As Cuordileone argues, the defense against Communism is also linked to a crisis in masculinity and anxieties about women's sexuality and entry into the workforce during WWII (526). Domesticity was then entrusted with the overwhelming task of "containing" deviant femininity as well as Communism.

\section{MULTIPLE PERSONALITY DISORDER, TRAUMA AND ABUSE IN THE BIRD'S NEST}

The Bird's Nest ${ }^{7}$ introduces Elizabeth Richmond, a shy, twenty-three-year-old orphan who lives with her aunt and works at a museum that "allowed of no concealment" (Nest 3), like her personality-apparently. When the museum's foundations begin to "sag" (Nest 3), Elizabeth's four split personalities will come to the fore, laying bare how her allegedly ideal nuclear family has failed her. In this way, external destruction undoes the structural workings of society, like the nuclear bomb threated to do. However, it is Elizabeth, and not her surroundings, the one who is scrutinized: after her first split takes place, she undergoes psychological treatment with Dr. Wright, where, under hypnosis, three other personalities are revealed. The split is signaled by the shifts in the narrative voice between the four personalities, Dr. Wright, Aunt Morgen and the final "healed" Elizabeth, whose chapter is told by a third person limited omniscient narrator.

Elizabeth Richmond, the outward and plain personality, splits into three more who battle for the control of Elizabeth's body. The second personality that arises is Beth, a sweeter, more compliant version of awake Elizabeth, or Elizabeth's façade of normative femininity and the one that Dr. Wright initially considers worth saving. The two remaining personalities gather Elizabeth's dark secrets and unfeminine misbehavior: Elizabeth's child-like personality, Betsy, is rude, angry and traumatized at the (hinted) sexual abuse she has suffered at the hands of her mother's boyfriend and her mother's enabling of it. ${ }^{8}$ Finally, Bess is the ruthless personality, aware of her wealthy inheritance that Aunt Morgen has taken over, and the one who believes to have committed matricide in

\footnotetext{
${ }^{7}$ Hereafter Nest.

8 Multiple personality disorder-or dissociative identity disorder, as it currently appears in the DSM V (2013) - is a form of PTSD that has been linked to sexual abuse in childhood in current diagnosis (Leys 79).
} 
a fit of rage against her mother. Bess is stuck at two weeks' time after her mother's death, while Betsy seems to have never overcome childhood: though traumatic events are never openly discussed, these blocked memories hinder growth in those personalities, creating instead new, more submissive ones to survive. This and other parallels in the novel prove that Jackson had read Morton Prince's The Dissociation of Personality: The Hunt For the Real Miss Beauchamp (1905) before writing Nest, ${ }^{9}$ since Dr. Wright even quotes Prince at key points of the narrative (Nest 58). Dr. Wright is, of course, a parody of Dr. Prince who will try to find "the real Miss Elizabeth Richmond," pathologizing Elizabeth's reaction to her traumatic experience, and will end up fabricating a suitable personality for Elizabeth in postwar America.

Interestingly enough, the narrative never suggests that there was a "whole" Elizabeth who was split in a particular moment and which must be "put together again," unlike Prince and even current theories seem to affirm about people who suffer from multiple personality disorder: "[1]ike Prince, present-day theorists of multiple personality tend to assume the existence of an already-constituted female subject comprised of a functional plurality or hierarchy of component parts to which violence comes entirely from the outside to shatter it into dysfunctional multiplicity" (Leys 79). Ruth Leys explains that this idea may be due to a "normalization of gender roles that represents the female subject as a completely passive victim" (Leys 79). Rather, the multiple splits seem to have happened at different times after traumatic events take place, allowing Elizabeth to dissociate, as each personality is associated with a different memory, and enables a different kind of survival behavior to be performed at the time. However, neither Prince nor Dr. Wright are so much interested in who is the original self or what caused the split, but rather on who is the most viable one in postwar society.

At first, Dr. Wright considers Beth, Elizabeth's most feminine personality, to be the most adaptive one to postwar women's roles; so much so that the doctor even thinks of himself "as setting free a captive princess" from the other Elizabeths (Nest 53), and imagines himself "much in the manner of a knight [...] who, in the course of bringing this true princess home, has no longer any fear, but only a great weariness, when confronted in sight of the castle towers by a

9 There is archival evidence in Jackson's letters for this assertion (CamineroSantangelo 57). 
great dragon to slay" (Nest 56). In fact, Dr. Wright makes romantic advances to Beth, presumably based on his knowledge of her rich inheritance (Nest 46), in order to "restore" Elizabeth's dysfunctional family: from being young, single, and living with her aunt, to starting a new family with also single Dr. Wright. But later he finds Beth too weak for not being able to fight off the other undesirable personalities: "too weak to remain consistently loyal" (Nest 146), that is, loyal to the project of the nuclear family and the nation. Thus, Dr. Wright sets off to build a new personality to his taste, "much like a Frankenstein with all the materials for a monster ready at hand" (Nest 143), contradicting his previous theories.

Yet the fact that Betsy's sexual abuse at the hands of her mother's boyfriend never comes to light during therapy signals both the failure of Dr. Wright's treatment-fulfilling Betsy's prophecy of nicknaming him Dr. Wrong (Nest 55) - and the impossibility of speaking up about power abuses within the nuclear family. Dr. Wright in fact takes advantage of his institutional power as he tries to tries to "right" and "write" 10 Elizabeth through his invasive means, full of sexual innuendos:

My problem was, specifically, to get back through the pipe to where the obstruction was, and clear it away. Although the figure of speech is highly distasteful to one as timid of tight places as myself, the only way in which I might accomplish this removal is by going myself (through hypnosis, you will perceive) down the pipe until, the stoppage found, I could attack it with every tool of common sense and clear-sighted recognition. There; I am thankful to be out of my metaphor at last, although I confess I think Thackeray might be proud of me for exploring it so persistently. (Nest 43)

In this affirmation, Dr. Wright considers the "cleaning of the pipe"-a metaphor for psychological rape he is aware of - a heroic deed, and he even likens himself to the author a Victorian novel. These novels usually dealt with the purity of the female protagonist or the lack thereof, and the world's attempt to take advantage over the girls' naïveté. However, while in nineteenth century traditional romantic plots women are the ones who marry up by means of sex and beauty, he is the one who covets Elizabeth's money and her ability to restore the nuclear family. In the end, one of the reasons

\footnotetext{
${ }^{10}$ For a further analysis on Dr. Wright's role as an author and masculine authority, see Caminero-Santangelo (58-68).
} 
why he fails to see Elizabeth's sexual abuse at the hands of her mother's boyfriend is that he suspects that Elizabeth's problem was her embarrassment at being sexually active: "I strongly suspected that what Miss R. meant by 'embarrassing' was precisely what any untutored young girl might mean by the world" (Nest 45). Wright's suspicions about Elizabeth's own sexual desires-probably closer to his own fantasy than to what she may ever articulate-make him overlook Elizabeth's past traumas and render her a perennial child, a practice that we find in Morton Prince's, Sigmund Freud's or Josef Breuer's cases. ${ }^{11}$ As Stanley Hall affirmed, along with Freud, adolescent girls would eagerly display "natural sexual impulses" in order to attract boys and men, orienting themselves, in their performance of femininity, "towards marriage and reproduction" (DeLuzio 39).

However, Marta Caminero-Santangelo reads the trend in the appearance of multiple personality disorder in popular culture as a representation of postwar anxieties about an all-too-powerful woman with "contradictory selves that could not coexist in a healthy, 'normal' woman" (53). In this sense, Elizabeth's split personalities show a lack of agency and the impossibility of complying with the expectations of society and developing an independent self. As Caminero-Santangelo affirms, "though multiple personality can be understood as a demand for the recognition of subjectivity, it ultimately demonstrates the absolute powerlessness of one who cannot completely claim the 'I' for herself" (58). Dr. Wright's solution, when he realizes that none of the four personalities is normal or desirable enough, is creating a new one-via making Elizabeth forget who she is: "Each life [...] asks the devouring of other lives for its own continuance" (Nest 254). It is not until Elizabeth declares one summer evening "I am through with remembering" (Nest 235) that she is considered "cured." This forgetting includes her traumas and her inheritance money, which would have been fully hers once she turned twenty-five, only a few months before her "recovery" (Nest 180). She is now an heiress to her society, as Dr. Wright points out: "[t]he creature at odds with its environment [...] must change either its own protective coloration, or shape the world in which it lives" (Nest 255). Shaping Elizabeth's own world proves impossible in Jackson's narrative.

11 See Rosenzweig (1987) for the possible aetiology of Beauchamp's personality split. For Dora's case, see Bernheimer and Kahane (1985). 
Thus, in the final chapter, entitled "The naming of an heiress," Elizabeth is renamed Victoria Morgen after her two corrective, surrogate parents, Dr. Victor Wright and Aunt Morgen. Not only that, but Aunt Morgen's spinsterhood is fixed as a collateral measure: Dr. Wright restores the status quo and makes a dysfunctional family functional-i.e., nuclear-again. In a way, Victoria Morgen becomes the Child that stands for "telos of the social order" (Edelman 11). "You can be her mommy, and I'll be her daddy," suggests Aunt Morgen, ironically subverting parental stereotypes because she is both described as masculine (Nest 8) and wealthy. While Victoria Morgen is more compliant than the former four Elizabeths, there is a slight hint of hope when she tells Dr. Wright, "You can't catch me, I'm the gingerbread man [...] Doctor Wrong. [...] I may be worse [...] I've run away from a little old woman and a little old man" (Nest 239). Her rebelliousness and her unfeminine new haircut, which she got without her Aunt's permission, could mean that Betsy is somehow still buried within her, and so is the potential to rebel against the social order. After all, Elizabeth resists the sexual and romantic advances of Dr. Wright, and turns into a daughter, not a wife-which might mean that she is still resisting the reproduction of the nation.

\section{THE POLITICS OF UNBELONGING IN THE HAUNTING OF HILL HOUSE}

The protagonist of The Haunting of Hill House, ${ }^{12}$ Eleanor Vance, has cared for her controlling, demanding mother all her life, only to find herself as an adult orphaned, single, friendless and penniless, despised and abused by her sister's family. ${ }^{13}$ Like Elizabeth in Nest, she has not had much adult experience nor love from others. The invitation of Dr. Montague to explore the paranormal energies of an old manor fills Eleanor's head with romantic fantasies of belonging, in a fairy-tale sort of narrative. In the house, Eleanor meets Luke and Theodora, who, together with Dr. Montague and his wife, form a new kind of family, one which resembles the nuclear family but differs from it in queer ways, as Lootens (2005) and Banks (2020) have identified.

\footnotetext{
12 Hereafter Hill House.

13 For instance, her sister's husband will not let Eleanor use their car to go to Hill House, even though Eleanor paid for half of it (Hill House 10).
} 
Eleanor, who "had spent so long alone, with no one to love" (Hill House 6), appears to be ready to have a family to belong to and love, hence "she fixes her fantasies both on Luke and Theodora" (Lootens 151). The choice will signify whether Eleanor consents to femininity and to the reproduction of the nation or not. As a projection of this fantasy, Eleanor singsongs Twelfth Night's phrase "Journeys end in lovers meeting" like a mantra throughout the novel. Shakespeare's play Twelfth Night presents the performativity of gender and sexuality, as two twins are mistaken for the one of the opposite sex, making allegedly heterosexual people fall in love with them. Despite the play's transgression, the ending is restored by the heterosexual marriage plot, ominously foreshadowing what will happen in Hill House. ${ }^{14}$ Ironically, Dr. Montague reads eighteenth century marriage-plot novels such as Pamela (1740) or Clarissa (1748), failing to recognize the parallel between the novels' protagonists and Eleanor, who is "the same sort of long-abused, unloved, and morally exacting woman as the heroines he reads about" (Roberts 88). If Elizabeth had four different personalities coexisting at once, Eleanor has none; in the manner of the girl, she is still defining herself through others, as we see in her first encounters with the other guests in Hill House: "And you are Theodora [...] because I am Eleanor" (Hill House 61). According to Catherine Driscoll, adolescent girls figure "mostly as a marker of immature and malleable identity, and as a publicly preeminent image of desirability" (2). These reciprocal definitions also allow for the creation of new personas: the first night, the guests invent theatrical characters for each of them as a whimsical game (Hill House 61-62). However, these identities will become fixed and normative, which will lead to Eleanor no longer being recognized as part of the family of Hill House.

In Theodora, Eleanor finds an equal companion for the first time. They self-describe as girls in a "boarding school" (Hill House 45), that is, a place for girls' development surrounded by sameness where they can explore their identity. ${ }^{15}$ According to Banks, lesbianism was portrayed in the 1950s "as erotic continuation of friendships between young girls" and "was central to the way many young women came to understand their sexual preferences" (179). As

\footnotetext{
${ }^{14}$ See Charles (1997) on gender, performance and sexuality in Twelfth Night.

${ }^{15}$ For the erotic undertones of the relationship between Eleanor and Theo, see Lootens (164).
} 
DeLuzio indicates, early twentieth-century scientific theories about normative sexuality claimed that a healthy sexuality in adolescent females included a "homosexual" period that girls would grow out of when heterosexuality was established (172). In fact, Theo is ambivalent towards Eleanor: when Eleanor proposes that they go and live together when they leave the house, escaping the nuclear family, Theo refuses. Theo also flirts effortlessly with both Eleanor and Luke, playfully exploring the possibilities of her sexuality in a way that only adolescence-broadly understood as not being an adult woman yet-allows. However, scientists also warned of the dangers "to the adolescent girl's psychological health if she failed to move on and achieve the developmental goal of heterosexual adjustment" (DeLuzio 172). In this sense, female adolescence becomes the necessary step to transition to normative heterosexuality, but it is also portrayed as a dangerous period of lingering between choices that may be irreversible once they have been made.

On the other hand, scientists did also attempt to define and justify the ways in which coming of age meant something different for men. In particular, endocrinologists charted how sexual hormones impacted bodily and sexual development differently (DeLuzio 173). In Hill House, Luke attempts to woo the two girls with the intention of fulfilling the marriage plot-and finding someone to replace the motherly role he lacks (Hill House 166). This upfront demand for unpaid labor shocks and upsets Eleanor, since Luke is "the only man [she] ever sat and talked to alone, and [she was] impatient" to meet him, yet she finds that "he is simply not very interesting," and proceeds to tell him to "grow up" by himself (Hill House 167). In this way, Eleanor unravels the intricate workings to tame girls into femininity via the fantasy of romantic love and belonging: "I am learning the pathways of the heart, Eleanor thought quite seriously, and then wondered what she could have meant by thinking any such thing" (Hill House 164). ${ }^{16}$ Even if her emancipatory discourse is constantly undermining itself, she refuses compulsory heterosexuality. In realizing how Luke's courting comes in between she and Theodora, Eleanor defines how the fantasy of romantic love

\footnotetext{
16 On the fantasy of romantic love as a way to tame women into femininity, see Berlant (2008). Since Eleanor reads her mother romance novels, Banks points out that Eleanor's "escape from maternal oppression is also an escape from the romantic narratives that were forced upon her" (175).
} 
and the promise of belonging stand in between a political alliance between women against patriarchy: "she wondered, and the thought was unwelcome, did Theodora know him as well as this?" (Hill House 166). Eleanor is well aware that family and society coerce girls into growing into a pre-defined identity that consists of caring for and fulfilling the demands of others. On her journey to Hill House, she encounters a family in a café with a little girl who refuses to drink milk from a cup that is not her own cup of stars, and thinks: "Don't do it [...] insist on your cup of stars; once they have trapped you into being like everyone else you will never see your cup of stars again" (Hill House 22). Later, we find that Eleanor used to have one herself, and wishes to get it back in her imaginary adult apartment, where she can live by herself, apart from others (Hill House 88), and where she does not have to follow social rules.

Thus, Eleanor's queerness and her refusal to go through with the heterosexual marriage plot brings the haunting of the house upon her: the group expels Eleanor from the "queer family"-now turned nuclear-of Hill House, deciding that "Eleanor has to go back the way she came" (Hill House 243). But since Eleanor does not want to leave the house, wishing to live there all alone or with a female companion like Hill House's original owner (Hill House 77), she disrupts the logic of nuclear power, replicating the queer female companion of the original owner (also a woman). The owner of Hill House, who left her house to her lesbian partner, broke the male lineage of property inheritance and was considered "a scheming young woman" (Hill House 80) because of this. However, Eleanor does not have any right of ownership over the house, and she is shunned from the group as soon as she appears to disturb their newly formed nuclear family by choosing Theo and rejecting Luke. Having nowhere to go, Eleanor ends up committing suicide. Critics such as Rubenstein (1996) and Lootens (2006) point to Eleanor's dominant mother as the source of her suicide; while Banks reads it in parallel with the tragic endings depicted in lesbian pulp novels in the 1950s due to the impossibility of exercising their queer desires (Banks 175). Under this reading, the unfeasibility of fulfilling the promise of the nuclear family, or of finding a queer alternative to which Eleanor can belong to, leads her to put an end to her life.

However, Brittany Roberts sheds light on how "the psychoanalytic model, which privileges human familial relationships and conventional domesticity, has led many critics to take the novel's ambiguously positive ending for a cruel tragedy" (73). Instead, 
Roberts aims to reconstruct the novel's complex relationships by claiming that Hill House "presents social isolation-perhaps even agoraphobia-not as a tragedy, but as a potential alternative route to female happiness and liberation" (73). In finding a home of her own and a self that she has never been allowed to explore, Eleanor fulfils a satisfactory alternative ending for her Gothic "fairy tale." Already at the beginning of the novel, when Eleanor begins her drive towards Hill House, we are told that she relishes in the journey (Hill House 14) and thinks about living alone somewhere (Hill House 22). The novel thus evinces how US postwar society rejects a woman who chooses a different path for herself-a woman who wishes to live alone and unmarried, without providing any of the care labor that femininity is bound to give as part of the family. Further, archival evidence shows that Jackson wanted to work on the ever-present haunting "emphasis upon (yippee) togetherness" (Jackson qtd. in Lootens 155) when she wrote Hill House. From Jackson's ironic celebratory exclamation, we can infer that she posited belonging as uncanny and disrupting for the self, who is constricted by external impositions. In breaking with the heteronormative fantasy of the heterosexual nuclear family and national belonging, Eleanor achieves a kind of freedom where she is not defined in relation to her place in society. Nevertheless, this alternative fantasy of solitude turns out to be death, which implies that it is impossible for Eleanor to become an adult woman in postwar America.

\section{CARE AND COMMUNITY IN WE HAVE ALWAYS LIVED IN THE CASTLE}

The key role of women in the material and symbolic reproduction of the family, like Elizabeth's in Nest and Eleanor's in Hill House is also central to We Have Always Lived in the Castle, ${ }^{17}$ Jackson's last completed novel, where the Blackwood family feeds its assets on the wealth of previous female generations: "as soon as a new Blackwood wife moved in, a place was found for her belongings, and so our house was built up with layers of Blackwood property weighting it, and keeping it steady against the world" (Castle 1), even though wealth is transmitted through male lineage. In the Blackwood house we find two sisters, Constance and Merricat, living in isolation

\footnotetext{
${ }^{17}$ Hereafter Castle.
} 
with their disabled uncle. Their parents and brother died of poisoning, and, although the village accused the elder sister Constance of killing them, the trial was abandoned for lack of proof. Merricat, the youngest sister, is the unreliable narrator, and the reader soon begins to suspect that she was the actual murderer, subverting our expectations for a teenager and stating the danger that girlhood actually entails.

The village, which they visit at times to buy groceries, despises the sisters not only for the murder, but also because of their financial independence, granted by their parents' inherited fortune. As Carpenter argues, "[h]aving vanquished one patriarchy, the women are confronted with another in the form of a village controlled by men, by other fathers" ("Establishment and Preservation" 35). Like the owner of Hill House, their refusal to form a nuclear family endangers the passing of wealth back to society. But soon, cousin Charles comes into their lives to take up the father's place and thus the sisters' fortune-we are told that he in fact looks like their father (Castle 57)-similarly to the way that Luke comes between Theo and Eleanor (Banks 174). Charles does not only try to usurp their fortune, but to reproduce the original nuclear family: Constance being the submissive, loving wife, and Merricat the devilish child who will be punished for not consenting to femininity, like she was punished by her parents because "she was a wicked, disobedient child" (Castle 34).18 Under Charles's influence, Constance is lured by the privilege that compulsory heterosexuality involves: belonging to the community, as Charles is accepted by it. Constance begins to think that they "should live like other people," even telling Merricat that she "should have boy friends"; Merricat then notes that "[Constance] began to laugh because she sounded funny even to herself" (Castle 82). The fact that Merricat sees this as a "performance" of gender (Butler 1990) that Constance is enacting signals the way that compulsory heterosexuality and femininity are consented to in order to access female maturity and being recognized as part of society.

However, Merricat's refusal to partake into this newly formed nuclear family that will try to tame her into femininity causes the destruction of its foundations. In order to expel Charles from their lives, Merricat sets the house on fire, which will have further

18 See Hall (1993), where she argues that Constance and Merricat actually display symptoms of the after-effects of sexual abuse. 
consequences: the death of their uncle-their last living male relative, besides from Charles-, the destruction and raiding of the remains of the house by their neighbors, and the sisters' end as women in society. In other words, the sisters' possibility of transitioning to a correct performance of femininity and womanhood comes to an end through Merricat's act: they will never leave the house again, they will have to subsist on their past female relatives' canned food, and they have to give up on marriage, having children, wearing feminine clothes, and rituals such as inviting family friends to their mother's tea room. They will even "have to wear Uncle Julian's clothes" (Castle 135), which points to the end of their existence as female members of the community. Before the fire, Merricat rightly notes that her sister "bur[ies] food the way [she] bur[ies] treasure" (Castle 42): while Merricat buries the family jewels, connected to their relatives' dowries, so as not to attract more covetous strangers, Constance and previous generations of Blackwood women stock up on what will feed the sisters for a lifetime. Thus, money is rendered irrelevant in this new economy of care; and food, which was hinted at as an expression of love19Merricat's punishment was often being sent to bed without dinner (Castle 94)-now becomes the currency for this new order: even the scared neighbors leave food as offerings to keep them at bay (Castle 139). Preservation and self-preservation are implied to be "the opposite of reproduction" (Banks 182), the way of not giving up their resources further down the male line. Thus, through the fire-that is, the symbolic destruction of their past and of the patriarchal orderthe sisters give up both patriarchy and capitalism.

The sisters are then transformed into witches in the town's lore: a neighbor claims that "[t]hey hate little boys and little girls. The difference is, they eat the little girls" (Castle 141). In other words, the village "contains" the sisters out of the fear that they may transform little girls into women like them, as this consumption is again linked to nurture and the transformation of the economy and society. As Stanley Hall affirmed in his 1904 study on adolescence, "girls everywhere shared a singular biological destiny, which could be ignored by themselves or their communities only at great biological, psychological, and social peril" (DeLuzio, 205). Edelman's idea of the child as the future of the nation (2004), and especially of little girls

19 See Ingram and Mullins (2018) and Muñoz González (2018) for an exploration of the role of food in Castle. 
as both future and reproducers of the nation, is embedded here, as the sisters may threaten the development of those girls into normative femininity and thus into the nuclear family. However, there are still gender roles in the small family formed by Merricat and Constance: Constance takes up the role of the mother who feeds, cares for and protects Merricat, while the latter has freed herself from the constraints of femininity. Merricat even romanticized Constance and "thought [she] was a fairy princess" when she was younger (Castle 19). Emily Banks points out that Castle and Hill House aim at the construction of a queer future and "in addition to complicating Edelman's concept of queer anti-futurity with her visions for an antinormative future, Jackson pushes against it by conceiving of alternative ways to collect, preserve, and produce that deviate from both heteronormative and capitalist standards" (181). However, while it is clear that Merricat rejects the maternal role, for she smashes a milk pitcher after Constance expresses her desire to go outside (Castle 27), ${ }^{20}$ Constance never has the chance to leave this role, perhaps because she has already "consented to femininity" and cannot escape this rationality any longer, or because of the ambivalence and lack of referents that complicate this kind of queer relationship, as we saw in the case of Eleanor and Theodora.

Although Merricat claims that "[they] are so happy" (Jackson, Castle 146), it is only her voice that we get to hear, so we might think that another form of oppression occurs, one where structures of power and gender roles are established between the sisters: Merricat mimics her tyrannical father; Constance is the caring Blackwood mother whose legacy will never be passed on. Thus, this new order is reminiscent of the old one, as though the remnants of the nuclear family were still haunting them in their confinement. As Wallace contends, the fact that the ending "restores equilibrium in the manner of traditional narrative might render [the story] [...] traditional" (185). Although Wallace problematizes Merricat's behavior as a response to challenging patriarchal structures, he admits that Merricat is "oddly empowering, a warped model of what can [...] be achieved once one claims one's own desires and forges an identity accordingly" (187). Thus, Merricat's ending might be a happy one, in the fairy-tale sense of restoring the roles Merricat and Constance had at the beginning of the novel, offering the sisters the

\footnotetext{
${ }^{20}$ Both Banks (178) and Rubenstein (318) point at the connection between milk and the rejection or acceptance of the maternal.
} 
ability to live isolated from the rest of the world in their own familial structure, but Constance's silence is revealing of her lack of options within and without the family.

\section{CONCLUSION}

This article has shown that Shirley Jackson's novels posit girlhood as a threat to US postwar society if girls refuse to perform normative femininity, following Butler's (1990) idea of gender as a performance, where the hierarchical relation between the binary genders is sustained by compulsory heterosexuality (Rich 1985). In this sense, girls in Jackson's novels are presented as disruptive elements which hinder the nuclear family from successfully establishing itself, or which may blow it up, as in the case of Merricat, who kills her parents and brother first and then removes cousin Charles and his expectations of marrying Constance from the house. The role of women in passing down their wealth and material legacy is also emphasized: for instance, Elizabeth in Nest has her four personalities erased and a new one created so that Dr. Wright and Aunt Morgen can get hold of her inheritance. Finally, Eleanor's queer leanings towards Theo threaten the new family at Hill House. All three protagonists end up refusing the heterosexual marriage plot and, therefore, their destiny-if they succeed in not "consenting to femininity" (de Lauretis 133). However, their identities are put at risk and are virtually annihilated. Like Elizabeth or Eleanor before their demise, they are infantilized; like Constance and Merricat, they are forever estranged from society. Likewise, belonging to a community is portrayed as crucial to survive, but also as life-threatening. The fixed roles of the nuclear family endanger its own stability, as anyone deviating from them in the slightest is considered to be a menace. Thus, these roles emphasize the fragile structure of the postwar nuclear family. Deviating girls must then be coerced into fitting back again into their assigned role, or otherwise eliminated lest they scatter these ideas around. Both the family and medical institutions are shown to be abusive, and since girls are perpetually rendered powerless-for becoming an adult woman means, following de Lauretis, accepting one's subordinate place in society-, Jackson's texts imply that it is not possible to belong to postwar US society as a woman who does not wish to "consent to femininity." 
Elizabeth, Eleanor and Merricat give up belonging to society after trying to be reoriented towards compulsory heterosexuality, normative femininity and the reproduction of the nation. Since they still have not crossed the threshold that turns them into women, they can renegotiate and create new spaces to exist outside the norm. These attempts are not proven fruitful-except, perhaps, in Merricat's case, to an extent, which in turn reproduces the nuclear family within her own confined house-for the main characters all end up losing agency and even their own lives. Nevertheless, their narratives question the given status quo and suggest the possibility of a different social order where girls are allowed to develop their own identity outside of gender mandates. However, "the destruction of the current world and the possibility of discovering something new" may go together (Banks 184). As Lauren Berlant and Lee Edelman affirm, "negativity signifies a resistance to or undoing of the stabilizing frameworks of coherence imposed on thought and lived experience" (xii). In undoing the coherence of the postwar nuclear family and resisting the reproduction of the nation, Jackson sheds light on how patriarchal rationality is entangled in the formation of female subjectivity and advocates for new forms of living.

\section{WORKS CITED}

AHMED, Sara. Cultural Politics of Emotion. 2004. Edinburgh UP, 2014.

BANKS, Emily. "Insisting on the Moon: Shirley Jackson and the Queer Future." Shirley Jackson and Domesticity, edited by Jill E. Anderson and Melanie R. Anderson. Blooomsbury, 2020, pp. 169-188.

BERLANT, Lauren. The Female Complaint: The Unfinished Business of Sentimentality in American Culture. Duke UP, 2008.

BERLANT, Laure and Lee Edelman. Sex, or the Unbearable. Duke UP, 2014.

BERNHEIMER, Charles and Clare Kahane, editors. In Dora's Case: FreudHysteria-Feminism. Columbia UP, 1985.

BUTLER, Judith. Gender Trouble: Feminism and the Subversion of Identity. Routledge, 1990.

CAMINERO-SANTANGELO, Marta. "Multiple Personality Disorder and the Postmodern Subject: Theorizing Agency." Shirley Jackson: Essays on 
the Literary Legacy, edited by Bernice Murphy. McFarland, 2005, pp. 52-79.

CARPENTER, Lynette. "Establishment and Preservation of Female Power in Shirley Jackson's We Have Always Lived in the Castle." Frontiers: A Journal of Women Studies, vol. 8, no.1, 1984, pp. 32-38.

---. "Domestic Comedy, Black Comedy, and Real Life: Shirley Jackson, a Woman Writer." Faith of a Woman Writer, edited by Alice KesslerHarris and William McBrien. Greenwood Press, 1988. 143-148.

CHARLES, Casey. "Gender Trouble in Twelfth Night." Theatre Journal, vol. 49, no. 2, pp. 1997, pp. 121-141.

CUORDILEONE, K.A. "Politics in an Age of Anxiety': Cold War Political Culture and the Crisis in American Masculinity, 1949-1960." Journal of American History, vol. 87, no. 2, 2000, pp. 515-545.

DE LAURETIS, Teresa. Alice Doesn't: Feminism, Semiotics, Cinema. Indiana UP, 1984.

DELUZIO, Crista. Female Adolescence in American Scientific Thought, 18301930. Johns Hopkins UP, 2007.

DRISCOLL, Catherine. "Girls Today: Girlhood, Culture." Girlhood Studies, vol. 1, no. 1, 2008, pp. 13-32.

EDELMAN, Lee. No Future: Queer Theory and the Death Drive. Duke UP, 2004.

FRASER, Nancy. Fortunes of Feminism: From State-Managed Capitalism to Neoliberal Crisis. Verso, 2020.

INGRAM, Shelley and Willow G. Mullins. "Would you Like a Cup of Tea?: Food, Home, and Mid-Century Anxiety in the Later Novels of Shirley Jackson." The Routledge Companion to Literature and Food, edited by Lorna Piatty-Farnel and Donna Lee Brien. Routledge, 2018, pp. 342350.

JACKSON, Kenneth. Crabgrass Frontier: The Suburbanization of the United States. Oxford UP, 1985.

JACKSON, Shirley. The Bird's Nest. Penguin, 2014.

---. The Haunting of Hill House. Penguin, 1984. 
---. We Have Always Lived in the Castle. Penguin, 2009.

HALL, Karen. "Sisters in Collusion: Safety and Revolt in Shirley Jackson's We Have Always Lived in the Castle." The Significance of Sibling Relationships in Literature, edited by JoAnna Mink et al. Bowling Green UP, 1993, pp.110-119.

HATTENHAUER, Darryl. Shirley Jackson's American Gothic. State U of New York P, 2003.

HUYSSEN, Andreas. "Mass Culture as Woman." After the Great Divide: Modernism, Mass Culture, Postmodernism, Indiana UP, 1987, pp. 3957.

LEYS, Ruth. "The Real Miss Beauchamp: An Early Case of Traumatic Dissociation." Trauma: A Genealogy, The U of Chicago P, 2000, pp. 41-82.

LOOTENS, Tricia. “'Whose Hand Was I Holding?': Familial and Sexual Politics in Shirley Jackson's The Haunting of Hill House." Shirley Jackson: Essays on the Literary Legacy, edited by Bernice M. Murphy. McFarland, 2005, pp. 150-168.

LUNBECK, Elizabeth. The Psychiatric Persuasion: Knowledge, Gender and Power in Modern America. Princeton UP, 1994.

MAY, Elaine Tyler. Homeward Bound: American Families in the Postwar Era. Basic Books, 1988.

MUÑOZ GONZÁLEZ, Esther. "Food Symbolism and Traumatic Confinement in We Have Always Lived in the Castle." Complutense Journal of English Studies, vol. 26, 2018, pp. 79-93.

NADAL, Marita. "Gothic and Trauma in Shirley Jackson's We Have Always Lived in the Castle." Between the Urge to Know and the Need to Deny: Trauma and Ethics in Contemporary British and American Literature, edited by Dolores Herrero and Sonia Baelo. Universitätsverlag Winter, 2011, pp. 161-74.

NASH, Iliana. American Sweethearts: Teenage Girls in Twentieth Century Pop Culture. Indiana UP, 2006.

OPPENHEIMER, Judy. Private Demons: The Life of Shirley Jackson. Putman, 1998. 
RICH, Adrienne. "Compulsory Heterosexuality and Lesbian Experience." Signs, vol. 5, no. 4, 1980, pp. 633-660.

ROSENZWEIG, Saul. "Sally Beauchamp's Career: A Psychoarchaeological Key to Morton Prince's Classic Case of Multiple Personality Disorder." Genetic Social and General Psychology Monographs, vol. 113, no. 1, 1987, pp. 5-60.

RUBENSTEIN, Roberta. "House Mothers and Haunted Daughters: Shirley Jackson and Female Gothic." Tulsa Studies in Women's Literature, vol. 15 , no. 2, 1996, pp. 209-331.

SCULL, Andrew. "Some Reflections on Madness and Culture in the Post-war World." History of Psychiatry, vol. 25, no. 4, 2014, pp. 395-403.

SCRUM, Kelly. Some Wore Bobby Sox: The Emergence of Teenage Girls' Culture, 1920-1945. Palgrave Macmillan, 2004.

WALLACE, Honor McKitrick. "The Hero Is Married and Ascends the Throne': The Economics of Narrative End in Shirley Jackson's We Have Always Lived in the Castle." Tulsa Studies in Women's Literature, vol. 22, no. 1, 2003, pp. 173-191. 